\title{
Point mutation of IL-10 1082 gene G/A at promoter region increased susceptibility of T2DM among Iraqi patients
}

\author{
Salih Abdul Mahdi khadim \\ AL-Qasim Green university-College of Biotechnology-Department of genetic engineering
}

\begin{abstract}
Several studies have shown that the role of cytokines closely linked with many human diseases. Recent studies have been discovered some relationship between interleukin -10 (IL-10) and type 2 diabetes mellitus (T2DM).On the other hand, some studies have been showed a close correlation between ethnic factors and the physiological reasons for many human diseases included T2DM; therefore, this study aimed to explore the effect of IL-10 G/A gene polymorphism at position 1082 among Iraqi patients, and its correlation with T2DM, through a study of sample consisted of 96 cases with T2DM and an equal number of healthy control subjects by using of allele refractory mutation system polymerase chain reaction (ARMS-PCR) technique. Our findings demonstrated that there is a statistically significant correlation of $I L-10-1082$ AA genotype between cases and control $(O R=1.63,95 \%$ CI 1.14-2.26, $P=0.03)$ and AA mutant genotype considered as risk factor of disease. Whereas no significant statistically effect of GG and GA genotypes frequency and T2DM disease.
\end{abstract}

Keywords: IL-10, polymorphism, T2DM, Iraqi patients

\section{Introduction}

Type 2 Diabetes mellitus is a group of abnormal physiological conditions in which the person produce insulin but the amount of insulin may be not enough or there is enough amount but that insulin not work in that individual's body because precise biological defects $(1,2)$. Most of studies summarized diabetes's reasons through two mechanisms. One of them impairs the function of pancreatic islet beta (B) cells and the second is impaired insulin action $(1,3)$. In 2008 reported that some pro- and anti-inflammatory cytokines secreted by mononuclear cell are one of most critical causes of dysfunction of pancreatic islet beta (B) cells as well as showed that the effect of IL-10 and IL-13 was associated with metabolic syndrome, type-2 DM, type-1 DM, and dyslipidemia (4,5). In 2010 the evidences are increased and improved that cytokines played critical roles in the procedures of pancreatic B cells function (6). That's where some cytokines such IL-1, tumor necrosis factor (TNF), leptine, resistine and adeponectine have been shown diversely adjust islet beta (B) cells function. Pancreatic B cells high chronic exposure to IL-1, TNF, interferon alpha (IFN- $\alpha$ ) promote the B cell dysfunction and apoptosis $(5,6)$.Other researchers demonstrated that pro-inflammatory cytokines like IL-6 and TNF- $\alpha$ associated with metabolic syndrome and T2DM 7, 9). As well as reported that TNF- $\alpha$ played vital role with insulin resistance, given that TNF- $\alpha$ and IL-6 lead to impair insulin action through down regulation of tyrosine kinase activity of the insulin receptor $(10,11,12)$. On the other hand some studies revealed that IL-6 impairs insulin sensitivity and the liver may be an important target of IL-6 (13).Concerning IL-10 which is the aim of this study is an anti-inflammatory cytokine and play as a immunosuppressive agent as well as act as a regulator of immune response (14). Production of IL-10 results in an efficient autocrine mechanism for regulating of proinflammatory cytokine production (15). Several studies reported that there is positive association between serum level of IL-10 and whole-body insulin sensitivity and have been shown that low IL-10 production was associated with hyperglycemia $(16,17)$. Therefore, in order to support the information series regarding T2DM disease and cytokines, the present study aimed to explore the association between IL-10 gene polymorphism and T2DM among Iraqi patients sample.

\section{Materials and Methods}

Total sample included 96 cases with T2DM; 51 male and 45 female and an equal number health control subjects; 47 male and 49 female. The mean age for cases and controls was 28.23 and 30.44 respectively. They were collected from consultative clinic of AL-Hashimiah General Hospital. All cases had a diagnosis of established T2DM on the bases of blood, urine tests, medical history, and clinical examinations. Genomic DNA extracted from Leukocytes by using of (Genomic DNA Extraction Kit- Bioneer Company). All samples were genotyped for IL-10 1082 G/A through (ARMS-PCR) technique as described in (Table 1). Amplification was carried out at conditions given in (Table 2). 
TABLE 1: Primers used in the present study and their product size

\begin{tabular}{|c|l|l|c|}
\hline $\begin{array}{c}\text { Polymorphism/ Allele } \\
\text { location }\end{array}$ & \multicolumn{1}{|c|}{ Primers } & \multicolumn{1}{|c|}{ Sequence } & $\begin{array}{c}\text { Product } \\
\text { size (bp) }\end{array}$ \\
\hline \multirow{2}{*}{ IL-10-1082G/A } & $\begin{array}{l}\text { Internal } \\
\text { control }\end{array}$ & $\begin{array}{l}\text { F: 5'-GTA AGC TTC TGT GGC TGG AGT C-3' } \\
\text { R: 5'-TTT CCA GAT ATC TGA AGA AGT CCTG-3' }\end{array}$ & 313 \\
\cline { 2 - 4 } & G \& A alleles & $\begin{array}{l}\text { F: 5'-AAC ACT ACT AAG GCT TCT TTG GGT A-3' } \\
\text { R: 5'-GTA AGC TTC TGT GGC TGG AGT C-3' }\end{array}$ & 161 \\
\hline
\end{tabular}

TABLE 2: PCR conditions for IL-10 1082 G/A gene

\begin{tabular}{|c|c|c|c|c|}
\hline S.NO & steps & Temperature & $\begin{array}{c}\text { No. of } \\
\text { cycles }\end{array}$ \\
\hline 1 & Denaturation & $95^{\circ} \mathrm{C}$ & 5 min & 1 \\
\hline 2 & Annealing & $95^{\circ} \mathrm{C}$ & $30 \mathrm{~s}$ & $30 \mathrm{~s}$ \\
\hline 3 & Annealing & $63^{\circ} \mathrm{C}$ & $5 \mathrm{~min}$ & 1 \\
\hline 4 & Extension & $72^{\circ} \mathrm{C}$ & 30 \\
\hline
\end{tabular}

\section{Statistical analysis}

$\mathrm{T}$ and Chi square tests were performed to find out whether there exists significant variation in age between cases and controls. The association between the candidate genes and risk of T2MD disease was estimated by computing OR and $95 \%$ CI using multivariate logistic regression analysis. The statistical analysis was performed using Epi-Info software (Epi-Info, version 3.5.1. centre for Disease Control and Prevention, Atlanta, GA, USA, August 13, 2008) and software SPSS version 11.5 (SPSS, Chicago, IL). Significance was set at $\mathrm{P}<0.05$.

\section{Results}

\section{- Characteristic of study subjects}

Regarding mean age and gender distribution, there was no statistically significant difference among cases and controls.

\section{- Distribution of 1L-10 -1082 G/A genotypes}

Table 3. Summarize the genotypes and allele frequencies for IL-10 G/A gene at position (1082) between cases and normal healthy controls subjects. Comparison results showed no significant association between cases and controls concerning heterogenotype G/A and the risk of disease (OR=1.10, 95\% CI 0.57$2.22, \mathrm{p}<0.75$ ). While the relationship between mutant homozygous A/A genotype in cases and control was statistically significant $(\mathrm{OR}=1.63,95 \%$ CI $1.14-2.26, \mathrm{P}<0.03)$. As well as the study showed a risk factor between A allele frequency and disease but statistically non significant ( $\mathrm{OR}=1.22,95 \% \mathrm{CI} 0.76-1.95, \mathrm{p}<0.38)$. It was found out that the frequencies of genotypes and alleles in cases and controls in the present study were in Hardy-Weinberg equilibrium.

Table 3. Distribution of genotypes and Alleles of IL-10 gene.

\begin{tabular}{|c|c|c|c|c|}
\hline IL-10 G/A & Cases n= 96 & Control n =96 & OR(95\%-CI) & P-value \\
\hline G/G & 47 & 49 & reference & 0.1 \\
\hline G/A & 38 & 36 & $1.10(0.57-2.22)$ & 0.75 \\
\hline A/A & 11 & 2 & $1.63(1.14-2.26)$ & 0.03 \\
\hline \multicolumn{5}{|c|}{ Alleles frequency } \\
\hline G & 132 & 134 & reference & 0.1 \\
\hline A & 60 & 40 & $1.22(0.76-1.95)$ & 0.38 \\
\hline
\end{tabular}

*Indicate significant $\mathbf{p}$ value

\section{Discussion}

Polymorphism is one of the most important ways that are used to determine point mutations in the genotypes. Single-nucleotide polymorphism (SNPs) is one of a pattern of polymorphism, which is defined as a variation of a DNA sequence nucleotides in the human genome. Such kinds of genetic variation occurring when a single nucleotide - A , T, C or G - in the genome differs between individuals of a biological species or matching chromosomes in a human $(17,18)$. For example, two sequenced DNA fragments from different individuals, AAGCCTA to AAGCTTA, contain a difference in single nucleotide sequencing. SNPs play a serious responsibility in the shifting of the amino acid sequence of protein then subsequently change of the proteins or enzymes functions $(18,19)$. Whereas, these genetic variations at coding parts of the genome underlie our susceptibility to disease $(20,21)$. DNA nucleotide sequence variations of humans genome can affect how humans susceptible and/or progress diseases and react with pathogens; chemicals, drugs vaccines, 
and other agents (22). Several studies showed that this type of genetic variation resulted in the changing of the quality and quantity of proteins; so from this biological entry we can access to interpret the results of this study, which showed that people with genetic formula AA genotypes they have a risk of disease $(\mathrm{OR}=1.63,95 \% \mathrm{CI}$ 1.14-2.26, $\mathrm{P}=0.03$ ). We believe that outcome of such this risk factor was due to firstly; the low production of IL10 in such AA genotype individuals consistently with previous studies which showed that individuals with IL10 (-1082) AA genotype produce low levels of IL-10 than GG and GA genotypes that's where plasma Interleukin-10 concentration is positively related to insulin sensitivity in healthy Individuals.(23) So IL-10 may made opposite action for effect of other Interleukins like IL-6 and TNF; as we mentioned in the introduction to the this study that high levels of TNF- $\alpha$ and IL-6 lead to impair insulin action through down regulation of tyrosine kinase activity of the insulin receptor while high levels of IL-10 can cause upregulation of tyrosine kinase activity of the insulin receptor $(24,25,26,27,28)$. Secondly; may be through the correlation between IL10 production capacity, high glucose and $\mathrm{HbA}$ since the association between IL-10 production capacity and glucose metabolism is real due to postprandial changes in $\operatorname{HbA}(29)$.Thirdly; may be through the effect of IL-10 as stimulator of insulin receptor substrate 2/P13-kinase/AKT pathway this proven by Jain and Singh $(30,31,32)$. All these interpretations may be non-curative. So more future studies concerning the interaction of genes (apistasis) and the net work of balance between pro and anti-inflammatory cytokines action and it's correlation with T2DM, certainly will give us clear vision about the real role of each cytokine and T2DM disease.

\section{Conclusion}

We concluded that there is a significant correlation between IL-10 A/A genotype at position 1082 and T2DM disease among Iraqi patients.

\section{Acknowledgments}

We thank all staff in consultative clinic of AL-Hashimiah General Hospital specially Dr. Saad joon, as well as my appreciation for all laboratory department staff for their helping to achievement this work.

\section{References}

[1]. Hall. J, Guyton and Hall's, Textbook of Medical Physiology, (Saunders Elsevier, Philadelphia, p. 950-951, 2012).

[2]. Ripsin CM, Kang H, Urban RJ, Management of blood glucose in type 2 diabetes mellitus, Am Fam Physician,79 (1),2009, 29-36.

[3]. Chang FY, Shalo MF, Decreased cell-mediated immunity in patients with non insulin-dependent diabetes mellitus, Diabetes Res Clin Pract, 28(2), 1999, 137- 46.

[4]. Eric van Exel,1 Jacobijn Gussekloo,1 Anton J.M. de Craen,1,2 Marijke Fro“lich,3 Annetje Bootsma-van der Wiel,1 and Rudi G.J. Westendorp1, Low Production Capacity of Interleukin-10 Associates, With the Metabolic Syndrome and Type 2 Diabetes, Diabtes, 51, 2002, $1088-1092$.

[5]. Monisha Banerjee and Madhukar Saxena, Genetic polymorphisms of cytokine genes in type 2 diabetes mellitus, World J Diabetes, 5(4), 2014, 493-504.

[6]. M.A.Varela and W. Amos, Heterogeneous distribution of SNPs in the human genome, Microsatellites as predictors of nucleotide diversity and divergence, Genomics, 95, 2010, $151-159$.

[7]. Y. Zhang, R. Proenca, M. Maffei, M. Barone, L. Leopold, and J. M. Friedman, Positional cloning of the mouse obese gene and its human homologue, Nature, vol. 372, 1994, 425 - 432. .

[8]. Festa A, D’Agostino R Jr, Howard G, Mykkanen L, Tracy RP, Haffner SM: Chronic subclinical inflammation as part of the insulin resistance syndrome: the Insulin Resistance Atherosclerosis Study (IRAS), Circulation, 102, 2000,42-47.

[9]. Feingold KR, Grunfeld C, Role of cytokines in inducing hyperlipidemi, Diabetes, 41, 1992, 97-101.

[10]. Hopkins PN, Hunt SC, Wu LL, Williams GH, Williams RR, Hypertension, dyslipidemia and insulin resistance: links in a chain or spokes on a wheel, Curr Opin Lipidol, 7, 1996, 241-253.

[11]. Hotamisligil GS, Budavari A, Murray D, Spiegelman BM, Reduced tyrosine kinase activity of the insulin receptor in obesitydiabetes: central role of tumor necrosis factor-alpha, J Clin Invest, 94, 1994, 1543-1549.

[12]. Hotamisligil GS, Peraldi P, Budavari A, Ellis R, White MF, Spiegelman BM, IRS-1-mediated inhibition of insulin receptor tyrosine kinase activity in TNF-alpha- and obesity-induced insulin resistance, Science, 271, 1996, 665-668.

[13]. Peter J. Klover, Teresa A. Zimmers, Leonidas G. Koniaris, and Robert A, Mooney, Chronic Exposure to Interleukin-6 Causes Hepatic Insulin Resistance in Mice, Diabetes,. 52, 2003, 223-231.

[14]. Moore KW, de Waal Malefyt R, Coffman RL, O’Garra A, Interleukin-10 and the interleukin-10 receptor, Annu Rev Immunol ,19, 2001, 683-765.

[15]. Donnelly RP, Freeman SL, Hayes MP, Inhibition of IL-10 expression by IFN-gamma up-regulates transcription of TNF-alpha in human monocytes, J Immunol, 155, 1995, 1420 -7.

[16]. Marek Straczkowski, Md Irina Kowalska, Md Agnieszka Nikoljuk, Phd Agnieszka Krukowska, Md Maria Gorska, Md. Plasma Interleukin-10 Concentration Is Positively Related to Insulin Sensitivity in Young Healthy Individuals, Diabetes Care, Vol. 28, No. 8, August, 2005.

[17]. van Exel E, Gussekloo J, de Craen AJM, Frolich M, Bootsma-van der Wiel A, Westendorp RGJ, Low production capacity of interleukin-10 associates with the metabolic syndrome and type 2 diabetes, Diabetes, 51, 2012,1088-1092.

[18]. Barreiro LB, Laval G, Quach H, Patin E, Quintana-Murci L, Natural selection has driven population differentiation in modern humans, Nature Genetics 40, 2008, 340-345.

[19]. Nachman, Michael W, Single nucleotide polymorphisms and recombination rate in humans, Trends in genetics, 17 (9), 2001, 481485 .

[20]. E. Kawasaki, N. Abiru, and K. Eguchi, Prevention of type 1 diabetes: from the view point of $\beta$ cell damage, Diabetes Research and Clinical Practice, vol. 66, 2004, supplement 1, pp. S27-S32, 
[21]. Wolf, A. B.; Caselli, R. J.; Reiman, E. M.; Valla, J, APOE and neuroenergetics, An emerging paradigm in Alzheimer's disease, Neurobiology of Aging, 2012.

[22]. Saxena M1, Srivastava N, Banerjee M, Association of IL-6, TNF- $\alpha$ and IL-10 gene polymorphisms with type 2 diabetes mellitus, Mol Biol Rep, 40(11), 2013, 6271-9.

[23]. Juliene Antonio Ramos, Rosane Silva, Luísa Hoffmann, Ana Lucia Araújo Ramos, Pedro Hernan Cabello5,Turán Péter Ürményi1, Cristiane Alves Villella-Nogueira3, Lia Lewis-Ximenez5 and Edson Rondinelli, Association of IL-10, IL-4, and IL-28B gene polymorphisms with spontaneous clearance of hepatitis C virus in a population from Rio de Janeir, BMC Research Notes, 5, 2012, p,508

[24]. Frohlich M, Imhof A, Berg G, Hutchinson WL, Pepys MB, Boeing H, Muche R, Brenner H, Koenig W, Association between Creactive protein and features of the metabolic syndrome, a population-based study, Diabetes Care, 23, 2000, 1835-1839.

[25]. Feingold KR, G runfeld C, Role of cytokines in inducing hyperlipidemia, Diabetes, 41 (Suppl 2), 1992, 97-101.

[26]. Hotamisligil GS, Budavari A, Murray D, Spiegelman BM, Reduced tyrosine kinase activity of the insulin receptor in obesitydiabetes: central role of tumor necrosis factor-alpha, J Clin Invest, 94, 1994, 1543-1549.

[27]. Hotamisligil GS, Peraldi P, Budavari A, Ellis R, White MF, Spiegelman BM, IRS-1-mediated inhibition of insulin receptor tyrosine kinase activity in TNF-alpha- and obesity-induced insulin resistance, Science, 271,1996, 665-668.

[28]. Hotamisligil GS, Peraldi P, Budavari A, Ellis R, White MF, Spiegelman BM: IRS-1-mediated inhibition of insulin receptor tyrosine kinase activity in TNF-alpha- and obesity-induced insulin resistance, Science 271,1996, 665-668.

[29]. Eric van Exel,1 Jacobijn Gussekloo,1 Anton J.M. de Craen,1,2 Marijke Fro“ lich,3 Annetje Bootsma-van der Wiel,1 and Rudi G.J. Westendorp1, Low Production Capacity of Interleukin-10 Associates With the Metabolic Syndrome and Type 2 Diabetes, Diabetes, 51, 2002, $1088-1092$.

[30]. Jian-Hua Zhou, Suzanne R. Broussard, Klemen Strle, Gregory G. Freund, Rodney W. Johnson, Robert Dantzer andKeith W. Kelley, IL-10 Inhibits Apoptosis of Promyeloid Cells by Activating Insulin Receptor Substrate-2 and Phosphatidylinositol 3 $\not$-Kinase, J Immunol, 167, 2001, 4436-4442.

[31]. James B. Crawley, Lynn M. Williams, Tom Manderł, Fionula M. Brennanand Brian M. J. Foxwell,Interleukin-10 Stimulation of Phosphatidylinositol 3-Kinase and p70 S6 Kinase Is Required for the Proliferative but Not the Antiinflammatory Effects of the Cytokine, Journal of Biological Chemistry,271, 1996,16357-16362.

[32]. Singh, Monica; Singh, Puneetpal; Juneja, Pawan Kumar; Singh, Surinder; Kaur, Taranpal, SNP-SNP interactions within APOE gene influence plasma lipids in postmenopausal osteoporosis, Rheumatology International, 31 (3), 2010, 421-3. 